\title{
Kömür Madeni İşletmelerinde Maddi Olmayan Duran Varlık Hesaplarının Incelenmesi: TKi-TTK ve Yeni Anadolu Madencilik ve Teknolojileri A.Ş. İşletmeleri Örneği
}

\author{
Examination of Intangible Assets Accounts in Coal Mining Operations: Case of Businesses; Tki, Ttk and Yeni \\ Anadolu Madencilik ve Teknolojileri A.S.
}

\author{
Erol Demir ${ }^{* 1}$ (D) \\ ${ }^{1}$ Faculty of Applied Sciences, Ankara University, Ankara, Turkey
}

\begin{abstract}
Received: 14.07 .2021
Accepted: 27.09 .2021

This article was checked by intihal.net

Öz

Enerji sektörünün önemli alanlarından biri olan kömür madenciliği alanında faaliyet gösteren iktisadi devlet teşekküllerinden Türkiye Kömür İşletmeleri Kurumu (TKi) ve Türkiye Taş Kömürü Kurumu (TTK) ile TKi'nin \%16'lık hisse ile iştiraki konumundaki Yeni Anadolu Madencilik ve Teknolojileri A.Ş. mali kayıtlarında yer alan fiziksel varlık ve maddi olmayan duran varlık hesaplarının yerinde yapılan inceleme ve araştırma çalışmaları sonucu elde edilen bulgular VUK, TMS ve TFRS esasları çerçevesinde değerlendirilmiştir. Belirtilen kömür madeni işletmelerinde kullanılan maddi olmayan duran varlık hesaplarından biri olan 260. Haklar hesabında; patent alımı, güvenlik yazılımı, kömür arama ruhsatı, microsoft yazılım lisansı, oracle veri tabanı, bitümlü şeyl sahaları, sahaların itfa bedeli, teleses bilgisayar program bedeli, bordro ve muhasebe programları, nes, netcad GIS ve netsurf lisans bedeli vb. varlıklardan oluştuğu görülmektedir. Söz konusu işletmelerin maddi olmayan duran varlık hesaplarının yeniden ele alınarak muhasebe sistemi uygulama genel tebliği, tek düzen hesap planı ve TMS/TFRS standartları çerçevesinde gerçeğe uygun değerleriyle finansal durum (bilanço) tablosunda raporlanması, raporlanamayan maddi olmayan duran varlık kalemlerine (entelektüel sermaye) ilişkin bilgilerin ise bilanço dipnotlarında ayrıntılı bir şekilde belirtilerek kayıtlara intikalinin sağlanması ve elde edilen sonuçların finansal olarak yorumlanması ve değerlendirilmesi açısından anlamlı olacağı ortaya konulmuştur.
\end{abstract}

Anahtar Kelimeler: Iktisadi Devlet Teşekkülleri, Türkiye Muhasebe Standartları, Maddi Olmayan Duran Varlık, Gerçeğe Uygun Değer

\section{Abstract}

One of the important areas of the energy sector is coal mining. The economic state enterprises operating in this field; Turkish Coal Enterprises Corporation (TKi), Turkish Hard Coal Authority (TTK) and Yeni Anadolu Madencilik ve Teknolojileri A.Ş., (which is a subsidiary of TKi with a $16 \%$ share) institutions constitute the sample of the study. The "intangible assets" accounts, which are included in the financial records of these institutions but provide commercial benefits and privileges to the companies in question, in addition to their physical assets, are examined. The findings obtained as a result of on-site examination and research studies were evaluated in terms of VUK (Tax Procedure Law) and TMS (Turkish Accounting Standards) principles. In the 260 Rights account, which is one of the intangible assets used in the mining operations within the scope of the review; patent acquisition, security software, coal exploration license, Microsoft software license, oracle database, office software program, security software, bituminous shale fields, redemption cost of fields, teleses computer program cost, office, payroll and accounting programs, Nes, Netcad GIS and netsurf license fee etc. appears to consist of assets. According to the results of the examination, the intangible asset accounts of the said enterprises should be reconsidered and reported in the operating balance sheets with their fair values in accordance with the general communique on the accounting system application, the uniform chart of accounts and TMS/TFRS standards. It has been demonstrated that the information on unreported intangible asset items (intellectual capital) is meaningful in terms of ensuring that it is recorded in the footnotes of the balance sheet and interpretation of the obtained results from a financial point of view.

Keywords: Public Economic Enterprises, Turkish Accounting Standards, Intangible Assets, Fair Value

Demir, E. (2021). Kömür Madeni İşletmelerinde Maddi Olmayan Duran Varlık Hesaplarının İncelenmesi: TKi-TTK ve Yeni Anadolu Madencilik Ve

Teknolojileri A.Ş. İşletmeleri Örneği. Journal of Academic Value Studies, 7(3), 382-393. http://dx.doi.org/10.29228/javs.52100

\footnotetext{
*E-mail address: dr.demirerol@gmail.com
} 


\section{Giriş}

Günümüz para ve sermaye piyasalarında yaşanan olumlu gelişmeler, muhasebenin temel kavram ve içeriklerinde de birtakım olumlu gelişmelerin yaşanmasına sebebiyet vermiştir. Bu bağlamda işletmelerin temel amaçlarının oldukça yüksek karlar elde etme esası yerine yüksek değerler oluşturma esasına dönüşmesi ve buna paralel olarak da muhasebe sisteminin "Kar/Zarar Odaklı" raporlamalardan "Değer Odaklı" raporlamalara dönüşmesi bu gelişmelerin en önemli sonuçlarından biri olarak değerlendirilmektedir. Önceki yıllarda söz konusu raporlamalarda maddi olmayan duran varlıkları türlerine göre sınıflama imkanı bulunmamaktaydı. Bugün itibariyle bilimsel teknolojilerin hızı bir şekilde ilerlemesi ve entelektüel faaliyetin sonuçları mülkiyet biçimlerinin sayısını artırmış ve karşımıza; doğal kaynakları kullanım hakkı, mülkiyet hakkı, entelektüel mülkiyeti ihtiva eden varlıklar (ticari marka ve telif hakkı), sanayi sektöründe mülkiyet nesneleri, şerefiye, işletme kültürü gibi iç güven unsuru sağlayan varlıklar ve diğer maddi olmayan duran varlıklar vb. bir grup çıkartmıştır. Ancak söz konusu mülkiyetlerin temel ve ek mali tablolarda dikkate alınabilmesi için gerçeğe uygun değerlerinin bilinmesine intiyaç duyulmaktadır. Zira maddi duran varlıklar gibi maddi olmayan duran varlıklar da tarihi maliyetlerle muhasebe kayıtlarına yansıtılmaktadır. Bu durumda, işletmelerin temel ve ek mali tablolarında yer alan muhasebe hesaplarının piyasa değerleri ile defter değerleri arasındaki fark giderek artmaktadır.

\subsection{Maddi Olmayan Duran Varlıklar ile Ilgili Ulusal Düzenlemeler}

a) MSUGT: Resmi Gazete'nin 26.12.1992 tarih ve 21447 sayılı mükerrer sayısında yayımlanan 1. No.lu Muhasebe Sistemi Uygulama Tebliğinin (MSUGT), "Düzenlemenin Amacı" başı|klı II. Bölümünde “...bilanço usulünde defter tutan gerçek ve tüzel kişilere ait teşebbüs ve işletmelerin faaliyet ve sonuçlarının sağlıklı ve güvenilir bir biçimde muhasebeleştirilmesi, mali tablolar aracılığı ile ilgililere sunulan bilgilerin tutarlılık ve mukayese edilebilirlik niteliklerini koruyarak gerçek durumu yansıtmasının sağlanması ve işletmelerde denetimin kolaylaştırılması" şeklinde bir düzenleme yapılmıştır. Söz konusu düzenleme ile;

a) Muhasebe bilgilerinin karar alma durumunda bulunan ilgililere yeterli ve doğru olarak ulaştırılmasına,

b) Farklı işletmeler ile aynı işletmenin farklı dönemlerinin karşılaştırılmasına,

c) Mali tablolarda yer alan hesap adlarının tüm kesimler için aynı anlamı vermesine,

d) Muhasebede terim birliğinin sağlanması suretiyle anlaşılabilir olmasına,

e) İşletmelerle ilgililer arasında güven unsurunun oluşturulmasına

imkan sağlanmaktadır (Anonim 1992).

MSUGT ile hayata geçen Tekdüzen Hesap Planı'nda 26. Maddi Olmayan Duran Varlıklar, herhangi bir fiziksel varlığı bulunmayan ve işletmenin belli bir şekilde yararlandığı veya yararlanmayı beklediği aktifleştirilen giderler ile belli koşullar altında hukuken himaye gören haklar ve şerefiyelerin izlendiği hesap grubudur (Anonim 1992). Bu hesap grubunda aşağıda belirtilen hesaplar yer almaktadır;

\section{MADDI OLMAYAN DURAN VARLIKLAR}

260. Haklar

261. Şerefiye

262. Kuruluş ve Örgütlenme Giderleri

263. Araştırma ve Geliştirme Giderleri

264. Özel Maliyetler

267. Diğer Maddî Olmayan Duran Varlıklar

268. Birikmiş Amortismanlar (-)

269. Verilen Avanslar

TMS 38 Maddi Olmayan Duran Varlıklar Standardı́nın konu ile ilgili düzenlemelerine bakıldığında ise; tanım olarak "maddi olmayan duran varlık", fiziksel niteliği olmayan tanımlanabilir parasal olmayan varlık olarak ifade edilmiştir (Anonim 2021a). TMS 38 ağırlıklı olarak işletmelerin kullandığı maddi olmayan duran varlıkların; sınıflandıııması, 
muhasebeleştirilmesi, değerlemesi, amortisman uygulamaları, değer düşüklüğü ve yenileme giderleri vb. konular üzerinde durmaktadır.

İncelenen işletmelerde maddi olmayan duran varlıkların birçoğunun çeşitli yazılım programlarından oluştuğu görülmektedir. Belirli bir süre ile sınırlandırımış lisans, ihtira beratı, ayrıcalık vb. maddi olmayan duran varlıkların söz konusu sürenin bitimi itibariyle işletmeler için bir değer ifade etmeyeceği dikkate alınarak, kendilerinden yararlanılan süreye göre amortismana tabi tutulmaktadırlar. Bu sürelerin sözleşmelerle belirlenmiş olması veya herhangi bir kamu kurum veya kuruluşlarınca onaylanmış olması gerekmektedir.

Bunların ilk satın alma maliyeti alı̧ fiyatı üzerinden belirlenmekte ve normal amortisman yöntemine göre ilgili iktisadi kıymetin ekonomik ömrü üzerinden itfa edilmektedir (5 yıl). Hesaplanan itfa payı tutarları ise muhasebede 770. Genel Yönetim Giderleri hesabı marifetiyle yansıtılmaktadır. TMS 38'e göre bir maddi olmayan duran varlık harcamasının sadece; (a) Varlıkla ilişkilendirilen gelecekteki ekonomik yararların işletme için gerçekleşmesinin muhtemel olması ve (b) Varlığın maliyetinin güvenilir bir şekilde ölçülebilmesi durumunda, muhasebeleştirileceğine yönelik görüşvardır (Anonim 2021b).

b) TTK: Türk Ticaret Kanunu'nun (TTK) 69. Maddesinde “...Yılsonu finansal tablolar; a) Türkiye Muhasebe Standartlarına uyularak düzenlenmeli, b) Açık ve anlaşılır olmalı, c) Düzenli bir işletme faaliyeti akışının gerekli kıldığı süre içinde çıkarılmalıdır", 88. maddesinde "...64 ilâ 88 inci madde hükümlerine tabi gerçek ve tüzel kişiler münferit ve konsolide finansal tablolarını düzenlerken, Kamu Gözetimi, Muhasebe ve Denetim Standartları Kurumu tarafından yayımlanan, Türkiye Muhasebe Standartlarına, kavramsal çerçevede yer alan muhasebe ilkelerine ve bunların ayrılmaz parçası olan yorumlara uymak ve bunları uygulamak zorundadır" denilerek TMS 38'in 79 ve 80. paragraflarında düzenlenen değerleme hükümlerine göre hareket edilmesi gerektiğine işaret edilmektedir.

Türk Ticaret Kanunu'nun "Şirketin Finansal Tabloları, Yedek Akçeler" başılılı 9. Bölümünün II - Dürüst resim ilkesi fıkrasına göre; "Madde 515 - (1) Anonim şirketlerin finansal tabloları, Türkiye Muhasebe Standartlarına göre şirketin malvarlığını, borç ve yükümlülüklerini, öz kaynaklarını ve faaliyet sonuçlarını tam, anlaşılabilir, karşılaştırılabilir, intiyaçlara ve işletmenin niteliğine uygun bir şekilde; şeffaf ve güvenilir olarak; gerçeği dürüst, aynen ve aslına sadık surette yansıtacak şekilde çıkarılır" denilerek muhasebenin temel işlev ve görevi açık bir şekilde ortaya konulmuştur.

c) VUK: Maddi olmayan duran varlıklar vergi mevzuatında "Gayri Maddi Haklar" şeklinde düzenlenmektedir. Gayrimaddi haklar, türleri ne olursa olsun gayrimenkuller gibi işleme tabidirler ve maliyet bedeli ile değerlenirler. İşletme bilançoda bağımsız olarak görülen hakkı, önceden kararlaştırılmış bir bedelle ediniyorsa edindiği o hakkı gayrimenkuller gibi maliyet bedeliyle değerleyecek, aktife alıp amortisman yoluyla yok edecektir. TMS 38 uyarınca işletmeye alınan maddi olmayan kıymetler maliyet bedeliyle aktife alınırlar (Anonim 2015). Buradan da görüleceği üzere iktisadi işletmelerin aktifinde kayıtlı maddi olmayan duran varlıklar, VUK hükümlerine göre değerlenmekte ve amortisman yoluyla itfa edilmektedirler.

\subsection{Maddi Olmayan Duran Varlıklar ile Illgili Uluslararası Düzenlemeler}

Uluslararası Finansal Raporlama Standartları'nın (UFRS) temel amacı; finansal bilgi kullanıcılarına karar verme süreçlerinde yararlı bilgiler sağlamaktır. TMS 38 Maddi Olmayan Duran Varlıklar Standardına göre düzenlenen işletme bilançolarında maddi olmayan duran varlıkların birçoğunun gerçeğe uygun değeriyle raporlanmadığı görülmektedir. Bu durum ise finansal tablo kullanıcılarına fayda sağlamak yerine onların yanlış kararlar almalarına sebebiyet vermektedir.

İşletmeler sıklıkla kaynak tüketir veya bilimsel ya da teknik bilgi, yeni süreç veya sistemlerin tasarım ve uygulanması, lisans, fikri mülkiyet hakları, piyasa bilgisi ve markalar (marka isimleri ve yayın hakları dahil) gibi maddi olmayan varlıkların elde etme, geliştirme, bakım veya iyileştirilmesi sırasında çeşitli borçlar yüklenmektedirler. Bu geniş kapsamlı başıklar altındaki kalemlerin yaygın örnekleri; bilgisayar yazılımı, patentler, telif hakları, sinema filmleri, müşteri listeleri, ipotek hizmeti sunma hakları, balıkçılık lisansları, ithalat kotaları, isim hakları, müşteri ve tedarikçi ilişkileri, müşteri sadakati, pazar payı ve pazarlama hakları maddi olmayan duran varlıklara örnek olarak verilmektedir (TMS 38, 2021, prf.9). Ancak Ar-Ge giderleri, kuruluş ve örgütlenme giderleri, eğitim ve reklam harcamaları, işletme içi oluşturulan şerefiye-marka-patent-lisanslar vb. kalemler işletme bilançolarında maddi olmayan duran varlıklar olarak raporlanamamaktadır. TMS 38 Maddi Olmayan Duran Varlıklar Standardı́na göre maddi olmayan bir duran varlığın aktifleştirilebilmesi için gerekli koşullar şunlardır (TMS 38, 2021, prf.11-17). Maddi olmayan duran varlığın diğer varlıklardan ayrıştııılabilir / tanımlanabilir olması, başkaları tarafından kullanımının kontrol edilebilir nitelikte olması, söz konusu varlığın kullanımından gelecekte ekonomik fayda sağlama potansiyelinin olması ve maliyetinin güvenilir bir 
biçimde ölçülebilir olması gerekmektedir. Bir maddi olmayan duran varlık, ilk muhasebeleştirilmesinin ardından, maliyetinden, tüm birikmiş itfa ve değer düşüklüğü zararları düşülmüş olarak izlenir. Bir maddi olmayan duran varlık, ilk muhasebeleştirilmesinin ardından, yeniden değerleme tarihindeki gerçeğe uygun değerinden birikmiş itfa ve değer düşüklüğü zararlarının tamamı düşüldükten sonra hesaplanan tutarı olan yeniden değerlenmiş tutarı üzerinden izlenir. Bu Standarda göre yeniden değerleme yapmak için, gerçeğe uygun değer, aktif bir piyasa ile ilişkilendirilmek suretiyle ölçülür. Yeniden değerleme işlemleri, raporlama dönemi sonunda ilgili aktifin defter değerinin gerçeğe uygun değerinden önemli ölçüde farklılık göstermemesi açısından düzenli olarak yapılır (TMS 38, 2021, prf.74-75). Işletme içi oluşturulan markalar, ticari başlıklar, yayın hakları, müşteri listeleri ve benzer nitelikteki kalemlerle ilgili harcamalar, işin bir bütün olarak geliştirilmesine ilişkin maliyetlerden ayırt edilemez. Bu nedenle, anılan kalemler maddi olmayan duran varlık olarak muhasebeleştirilmez (TMS 38, 2021, prf.64). Bize göre işletme içerisinde oluşturulan marka ve kullanıldıkça değeri artan diğer maddi olmayan duran varlıkların, bilançonun pasifinde özkaynaklar grubu içerisinde "Entelektüel Sermaye" olarak raporlanabileceği, bilgi temelli rekabetin yaşandığı 21. yüzyılda harekete geçirilmesi gereken önemli bir güç olarak değerlendirilmektedir.

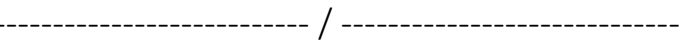

260. Haklar

$x X X$

260.01.0001 Patent

529. Diğer Sermaye Yedekleri

$x x x$

529.01.0001 Entelektüel Sermaye

-

260. Haklar: Imtiyaz, patent, lisans, ticari marka ve unvan gibi bir bedel ödenerek elde edilen bazı hukuki tasarruflar ile kamu otoritelerinin işletmeye belirli alanlarda tanıdığı kullanma, yararlanma gibi yetkiler dolayısıyla yapılan harcamaları kapsar (Anonim 1992). Üretim lisansları ve haklar için ödenen değerler varlık olarak bilançonun aktifine maliyet bedelleri ile kaydedilirler.

261. Şerefiye: Bir işletme devralınırken katlanılan maliyet ile söz konusu işletmenin rayiç bedelle hesaplanan net varlıklarının (öz varlık) değeri arasındaki olumlu farkların izlenmesinde kullanılır. Şerefiye hesaplanırken rayiç bedelin tespit edilmemesi halinde, net defter değeri esas alınır (Anonim 1992). Vergi Usul Kanunu, devir alınan işletmenin varlık ve borçları arasındaki farktan oluşan net varlıklarının emsal değeri ile satın alınan işletmenin ödediği satış bedeli arasındaki farktan oluşan "Şerefiye" yerine "Peştamallık" kelimesini kullanmıştır (Anonim 1992). Maddi olmayan bir unsuru ifade etmesine rağmen peştamallıklar, gayrimaddi haklardan farklıdırlar. Gayrimaddi haklar zilyetliğe konu olabildiklerinden alınabilmekte, satılabilmekte veya devredilebilmektedir. Ama peştamalığın alımı veya devri mümkün değildir (Anonim 2015). TMS 38 Standardı kapsamında işletme içi oluşturulan şerefiye aktifleştirilememektedir. Ayrıca TMS 38 Maddi Olmayan Duran Varlıklar Standardı ile birlikte KOBi TFRS esaslarına göre de işletme içi oluşturulan maddi olmayan duran varlıklar (lisans, marka, patent, web sitesi, yazılım programı, vb.), gerçeğe uygun değerleri ile temel mali tablolarda gösterilememektedir. Bize göre bu durum son derece yanlıştır. Söz konusu standartta yapılacak bir düzenleme ile işletme içi oluşturulan şerefiyeyi de kapsayacak şekilde yeniden bir varlık tanımı yapılmasında yarar bulunmaktadır.

262. Kuruluş ve Örgütlenme Giderleri: Kuruluş ve örgütlenme giderlerinin işletmeye herhangi bir fayda sağlama özelliği bulunmadığından dolayı maddi olmayan duran varlıkların içerisinde yer almamaktadır.

263. Araştırma ve Geliştirme Giderleri: İşletmede yeni ürün ve teknolojiler oluşturulması mevcutların geliştirilmesi ve benzeri amaçlarla yapılan her türlü harcamalardan, aktifleştirilen kısmının izlendiği hesaptır (Anonim 1992). Tanımdan da anlaşılacağı üzere Tekdüzen Hesap Planı, söz konusu giderlerin aktifleştirileceği gibi doğrudan da gider yazılabileceği yönündedir. Ancak TMS 38'e göre işletme içi oluşturulan bir maddi olmayan duran varlığın muhasebeleştirilebilmesi için gerekli kriterleri sağlayıp sağlamadığının değerlendirilmesinde işletme, ilgili varlığın oluşumunu şu safhalara ayııır: (a) Araştırma safhası ve (b) Geliştirme safhası. "Araştırma" ve "geliştirme" terimleri tanımlanmış olmalarına rağmen, 'araştırma safhası' ve 'geliştirme safhası' terimleri bu Standart açısından daha geniş bir anlam taşır (TMS 38, 2021, prf.52). Bir işletmenin, bir maddi olmayan duran varlık oluşturulmasına ilişkin işletme içi bir projenin araştırma safhasını geliştirme safhasından ayırt edememesi durumunda, söz konusu projeye ilişkin harcamaları sadece araştırma safhasında yapıımış gibi dikkate alınır (TMS 38, 2021, prf.53). Bir başka ifadeyle Ar-Ge faaliyetleri 
birbirlerinden ayrıştırılabiliyorsa, araştırma harcamaları aktifleştirilememekte, ancak geliştirme harcamaları aktifleştirilebilmektedir.

267. Diğer Maddî Olmayan Duran Varlıklar: Eğitim ile ilgili harcamaların, işletmeye herhangi bir katkı sağlama özellikleri bulunmadığından dolayı maddi olmayan duran varlık hesapları içerisinde yer almaları söz konusu değildir. Reklam harcamalarının, gelecekte işletmeye sağlayacağı faydanın ölçülebilir nitelikte olmaması nedeniyle dönemin gideri olarak gelir tablosunda yer alması sağlanmalıdır. Ancak satın alınan veya işletme içerisinde üretilen bilgisayar işletim programı ve yazılımları bilançoda maddi olmayan duran varlıklar kalemi içerisinde aktifleştirilebilme imkânına sahiptirler.

Incelenen işletmelerin maddi olmayan duran varlık hesapları incelendiğinde;

a) Türkiye Taşkömürü Kurumu

260. Haklar Hesabı

370.000.-TL

267. Diğer Maddi Olmayan Duran Varlıklar Hesabı

3.712.000.-TL

268. Birikmiş Amortismanlar (-) Hesabı

1.086.000.-TL

Tablo 1: Türkiye Taşkömürü Kurumu Muhasebe Kayıtlarında Yer Alan Maddi Olmayan Duran Varlıklar

\begin{tabular}{|c|c|c|}
\hline \multirow[b]{2}{*}{ 26. MADDI OLMAYAN DURAN VARLIKLAR } & \multicolumn{2}{|c|}{ TTK } \\
\hline & $\begin{array}{c}\text { Yardımcı } \\
\text { Hesap }\end{array}$ & Ana Hesap \\
\hline 260. HAKLAR & & 370.000 \\
\hline Temsan (Patent Alımı) & 370.000 & \\
\hline 267. DiĞER MADDÎ OLMAYAN DURAN VARLIKLAR & & 3.712 .591 \\
\hline İstanbul Pazarlama Yazılım (Akrobat Pro DC) & 1.340 & \\
\hline DMO Yazılım (İç Kontrol Kamu Modeli) & 107.479 & \\
\hline Kardelen Yazılım (E-Reçete Yazılımı) & 4.200 & \\
\hline Redon (CNC Tezgahı CAM Yazılımı) & 84.496 & \\
\hline Risk Management Risk Analiz Yazılımı (İş Sağlığı ve Güvenliği) & 28.101 & \\
\hline Oska Bilgisayar (Hakediş ve Kesin Hesap Programı) & 22.400 & \\
\hline Dört Us Bilişim Yazılım (Yetkilendirme ve geçiş takip) & 9.750 & \\
\hline Comodo Yazılım A.Ş & 2.025 & \\
\hline İdeasis Bilişim Teknolojileri (Üzül Müd. Ev. Müze Projesi) & 231.500 & \\
\hline Bilmar Bil.Sis.Ltd. Şti. & 3.800 & \\
\hline KBM Bilgisayar Ltd.Şti. (TAKBIS Sorgu Portalı) & 17.500 & \\
\hline Karadon Rehabilitasyon etüdü & 3.200 .000 & \\
\hline 268. BIRIKMIŞ AMORTiSMANLAR (-) & & 1.086 .483 \\
\hline Haklar & 24.666 & \\
\hline Diğer Maddi Olmayan Duran Varlıklar & 1.061 .817 & \\
\hline Genel Toplam & & 2.996 .108 \\
\hline
\end{tabular}


b) Türkiye Kömür İşletmeleri Kurumu

260. Haklar Hesabı

161.775.000.-TL

263. Ar-Ge Giderleri Hesabı

6.450.000.-TL

267. Diğer Maddi Olmayan Duran Varlıklar

4.826.000.-TL

268. Birikmiş Amortismanlar (-) Hesabı

85.623.000.-TL

Tablo 2: Türkiye Kömür İşletmeleri Kurumu Muhasebe Kayıtlarında Yer Alan Maddi Olmayan Duran Varlıklar

\begin{tabular}{|c|c|c|}
\hline \multirow[b]{2}{*}{ 26. MADDI OLMAYAN DURAN VARLIKLAR } & \multicolumn{2}{|c|}{ TKI } \\
\hline & $\begin{array}{l}\text { Yardımcı } \\
\text { Hesap }\end{array}$ & Ana Hesap \\
\hline 260. HAKLAR & & 161.775 .483 \\
\hline Güvenlik Yazılımı & 405.440 & \\
\hline Kırklareli 6 Adet Kömür Arama Ruhsatı (MTA.'dan devir) & 84.566 .680 & \\
\hline Konya 2 Adet Kömür Arama Ruhsatı (MTA.'dan devir) & 38.710 .100 & \\
\hline Microsoft Yazılım Lisansı & 561.276 & \\
\hline Oracle Veri Tabanı & 4.824 .000 & \\
\hline Office Yazılım Programı & 690.000 & \\
\hline Güvenlik Yazılımı & 1.380 .000 & \\
\hline Bolu Göynük Bitümlü Şeyl Sahaları & 30.637 .987 & \\
\hline 263. ARAŞTIRMA ve GELIŞTIRME GIDERLERI & & 6.450 .228 \\
\hline Kömürün Briketlenmesi Kurutulması Projesi & 15.600 & \\
\hline Sentez Gazından Metanor Üretim Çalışması & 3.000 & \\
\hline Uzaktan Kontrollü Maden Robotu & 250.000 & \\
\hline $\begin{array}{l}\text { Linyit Gaz Temiz Enerji Üret. Sıvı Yakıt veya } \\
\text { Muht.Kimy.Mad.Ürt.Kull.Projesi }\end{array}$ & 69.691 & \\
\hline LInI Yeraltı Kömür Gazlaştırma Projesi & 1.337 .182 & \\
\hline Mevcut Teknolojiler İle Kömür Haz.- & 308.476 & \\
\hline Isıl Değeri Düşük Kömürlerin Külsüzleştirilmesi & 588.000 & \\
\hline Leonarditten Yüksek Fülvik Asit İçerikli Sıvı Hümat Prj. & 39.000 & \\
\hline Prefabrik Kapalı Alan & 27.000 & \\
\hline 3 Takım Kömür/Hava Besleme Boru Hattı Temini & 414.000 & \\
\hline (Ar-Ge) Bitümlü Şeyl.Yat.Solvent Ekst.Yönt.Sıvı Yakıt Üretim Pot.Araş. & 300.000 & \\
\hline (Ar-Ge) Türkiye Lin.Köm.Biriket.Koşul.Belir.Biriket ve Ambalaj Malz.Geliş. & 300.000 & \\
\hline Prefabrik Kapalı Alan Mimari Proje Masrafları & 18.000 & \\
\hline
\end{tabular}




\begin{tabular}{|c|c|c|}
\hline $\begin{array}{l}\text { (Ar-Ge) Isıl Değ.Düşük Köm.Ekst.Yönt.ile Külsüzleştirme ve Alternatif Ürün } \\
\text { Geliş. }\end{array}$ & 250.000 & \\
\hline Tesis; Proje ve Ar-Ge Giderleri & 27.000 & \\
\hline Organik Toprak Düz.Sera Ve Tarla Den. & 237.698 & \\
\hline Lab.Ölç.H.Ast İç.Adsorban Es.Alt Mad.Gel & 260.000 & \\
\hline İr:1150 Saha Bitümlü Şeyl.Araşt. & 350.964 & \\
\hline Mevcut Tek.Köm.Haz.Çalış.Hac.Ünv. & 188.500 & \\
\hline Hümik Asit Esaslı Mad.Üretim Prj. & 100.000 & \\
\hline Çevresel Durum Değerlendirme Prj. & 150.000 & \\
\hline Kömür Karakter Ve Yanma Dav.Inc.Prj & 25.000 & \\
\hline Leonarditten Yüksek Fülvik Asit İçerikli Sıvı Hümat Prj. & 9.000 & \\
\hline Leonardit.Yüksek Fülvik As.liç.Sıvı Humat & 117.000 & \\
\hline Hümas(Potsym Humat)Verm Parmet.Ana Buz. & 27.000 & \\
\hline Organik Toprak Düz.Sera Ve Tarla Den. & 54.000 & \\
\hline $\begin{array}{l}\text { Hümatların Seramik Sağlık Gereçleri Ve Seramik Kaplama Malzemeleri } \\
\text { Üretiminde Dağıııı Olarak Kullanımının Araş. }\end{array}$ & 40.510 & \\
\hline Isıl Değ. Düşük Köm. Ext.Yön.Külsüzleş. & 200.000 & \\
\hline Linyit.Köm.Biriketleme Ve Ambalaj Geliş. & 300.000 & \\
\hline Bitümlü Şeyl Saha Etüd.Araş. Danışmnalık & 31.500 & \\
\hline $\begin{array}{l}\text { Hümik Asitin Çimento Ve Betonda Kimyasal Katkı Malzemesi Olarak } \\
\text { Kullanılması Projesi }\end{array}$ & 42.107 & \\
\hline $\begin{array}{l}\text { Kükürt Giderme ve Isıl Değeri Artırma Amacıyla Kömür Katkı Maddelerinin } \\
\text { Geliştirilmesi Projesi }\end{array}$ & 120.000 & \\
\hline $\begin{array}{l}\text { Lavvar Ürün. Değ. Susuzland. Konularında Arge Çlşm. Yeni Ve Yerli Tekn. } \\
\text { Gelşt. }\end{array}$ & 150.000 & \\
\hline $\begin{array}{l}\text { Kükürt Giderme Ve Isıl Değeri Artırma Amacıyla Kömür Katkı Maddelerinin } \\
\text { Geliştirilmesi Projesi }\end{array}$ & 100.000 & \\
\hline 267. DiĞER MADDÎ OLMAYAN DURAN VARLIKLAR & & 4.826 .224 \\
\hline Ağ Erişim Kontrol Yazılımı & 308.000 & \\
\hline Pazarlama Satış Ve Saha Yönetim Yazılımı & 1.273 .972 & \\
\hline Yazılım Hizmetleri & 40.888 & \\
\hline Masaüstü Sanallaştırma Yazılımı Sunucusu & 120.000 & \\
\hline Mobil Cihaz Yönetimi & 923.450 & \\
\hline Labris Flexd 700 Güvenlik Programı & 347.878 & \\
\hline Labris Felxd 750 Güvenlik Programı & 254.473 & \\
\hline Rfıd Demirbaş Takip Programı & 18.954 & \\
\hline Labris Flexd 160 Ve Labris Mng 25I Güvenlik Prog. & 192.372 & \\
\hline
\end{tabular}




\begin{tabular}{|l|r|r|}
\hline Personel Kimlik Kartı Program Yazılımı & 19.000 & \\
\hline Restoran Otomasyon Program Yazııııı & 76.480 & \\
\hline Tedaş Siber Güvenlik Sistemi & 211.438 & \\
\hline Kat Yazıııı Yazıımı & 60.480 & \\
\hline Emc Rpa Yedekleme Yazıımı (2 Adet) & 34.878 & \\
\hline Madencilik Programı & 322.961 & \\
\hline Nfc Temassız Ödeme Yazıııı(Lokal, Çay Ocağı, Didim Ve Akçay İçin) & 56.000 & \\
\hline Nfc Temassız Ödeme Yazııımı(Lokal, Çay Ocağı, Didim Ve Akçay İçin) & 65.000 & \\
\hline Elektronik Belge Yönetimi Sistemi (EBYS) & 500.000 & \\
\hline 268. BiRikMiş AMORTiSMANLAR (-) & & $\mathbf{8 5 . 6 2 3 . 9 0 7}$ \\
\hline Haklar & 77.871 .428 & \\
\hline Araştırma ve Geliştirme Giderleri & 4.133 .715 & \\
\hline Diğer Maddi Olmayan Duran Varlıklar & 3.618 .764 & \\
\hline \multicolumn{1}{|c|}{ Genel Toplam } & & $\mathbf{8 7 . 4 2 8 . 0 2 9}$ \\
\hline
\end{tabular}

c) Yeni Anadolu Madencilik ve Teknolojileri San. Tic. A.Ş.

260. Haklar Hesabı

592.000.-TL

268. Birikmiş Amortismanlar (-) Hesabı

29.000.-TL olduğu görülmektedir.

Tablo 3: Yeniçeltek A.Ş. Muhasebe Kayıtlarında Yer Alan Maddi Olmayan Duran Varlıklar

\begin{tabular}{|l|r|r|}
\hline \multicolumn{1}{|c|}{ 26. MADDI OLMAYAN DURAN VARLIKLAR } & \multicolumn{2}{c|}{ YENIÇELTEK } \\
\cline { 2 - 4 } & $\begin{array}{c}\text { Yardımcı } \\
\text { Hesap }\end{array}$ & Ana Hesap \\
\hline \hline 260. HAKLAR & 430.799 & 592.169 \\
\hline iR-486 no'lu Bolu ilindeki sahanın itfa bedeli & 165 & \\
\hline Teleses bilgisayar programı bedeli & 161.205 & \\
\hline $\begin{array}{l}\text { Office, bordro ve muhasebe programları, nes, netcad GIS ve netsurf lisans } \\
\text { bedeli }\end{array}$ & & 29.641 \\
\hline 268. BiRiKMiş AMORTiSMANLAR (-) & 29.641 & \\
\hline Haklar & & 562.528 \\
\hline \multicolumn{1}{|c|}{ Genel Toplam } & & \\
\hline
\end{tabular}

\subsection{Maddi Olmayan Duran Varlıkların Finansal Durum Tablosuna Olan Etkileri}

TMS 38 Maddi Olmayan Duran Varlıklar Standardı esaslarına göre bir işletme Ar-Ge çalışmalarına ilişkin sonuçları birbirinden ayıramadığı sürece katlandığı maliyetlerin araştırma safhasında yapıldığı kabul edilmektedir. İnceleme kapsamında yer alan kömür madeni işletmelerinde söz konusu Ar-Ge harcamalarının tamamı gider olarak kaydedilmekte ve bunların aktifleştirilmesi söz konusu olmamaktadır. Bu durumda ise işletmeler tarafından düzenlenen temel mali tablolarda yer alan aktif ve pasif hesaplar (karlar) gerçeği yansıtmayacaktır. Ayrıca maddi olmayan duran varlık kalemleri 
arasında yer alan ve işletmeler açııından son derece önem arz eden "marka değerinin" finansal tablolarda sunumuna yönelik olarak yapılan çelişkili açıklamalar gerçeğe uygun değerin oluşumunda çok büyük engel oluşturmaktadır. Oysaki işletmelere yönelik gerçeğe uygun, anlaşılabilir, şeffaf, güvenilir mali veriler kullanılarak (özellikle BIST’te işlem gören işletmeler açısından. Çünkü potansiyel yatırımcılar işletmelerin sahip oldukları marka/şerefiye değerine ilişkin bilgileri birtakım danışmanlık firmalarından elde etmeye çalışmaktadırlar) hazırlanan temel ve ek mali tablolarda yer alan muhasebe hesap kalemlerinin defter değerleri ile rayiç değerleri arasında oluşacak farkın minimum düzeye indirilmesi temel amaç olarak benimsenmelidir. Örnek olarak incelenen çalışmada, örnek işletmenin mevcut mali kayıtlarına göre maddi duran varlıklarının toplam değerinin (8.872.054,07 TL), söz konusu varlıkların güncel değerinden (54.342.356,11 $\mathrm{TL}$ ) yaklaşık 6 kat daha düşük olduğunu tespit etmiş ve bu nedenle işletmenin varlık değerinin mali kayıtlarda olduğundan çok daha düşük olarak yer aldığını ortaya koymuşlardır (Aliefendioğlu vd 2016).

İnceleme kapsamında yer alan işletmelere (TKI, TTK ve Yeni Anadolu A.Ş.) ait kömür madeni sahalarının rödovans karşılığı verilen sözleşmeler incelendiğinde maden işletmecisi, belirlenen üretim yılları için taahhüt ettiği miktarın altında üretim yapmış olsa dahi yıllık olarak taahhüt edilen miktar üzerinden hesaplanan rödovans tutarını ödemekle mükellef olduğu görülmüştür. Taahhüt edilen asgari üretim miktarının üzerinde üretim yapması halinde ise rödovans tutarını ayrıca ödeyecektir. Bilindiği üzere maliyetlerin muhasebeleştirilmesi işlemlerinde üretim maliyetleri hesaplanırken hammadde malzeme, işçilik ve genel üretim giderlerinin yanı sıra atıl kapasiteye ilişkin maliyetlerin de dikkate alınması gerekmektedir. Atıl kapasite ile ilgili maliyetlerin muhasebeleştirme ve raporlama esasları TMS-2 Stoklar standardı paragraf 13 'te “...Her bir üretim birimine dağıtılan sabit genel gider miktarı, düşük üretim düzeyi veya atıl kapasite nedeniyle arttırılmaz. Dağıtılmayan genel giderler, gerçekleştiği dönemde gider olarak finansal tablolara yansıtıır". Paragraf 38 ' de ise "...Genellikle satışların maliyeti olarak ifade edilen ve dönem içinde gider olarak finansal tablolara yansıtılan stokların tutarı, satılmış olan stokların ölçümüne daha önce dâhil edilmiş maliyetlerden, dağıtılmamış genel üretim giderlerinden ve normalin üstünde gerçekleşen üretim maliyetlerinden oluşur" denilmektedir. Buna göre kömür madeni işletmelerince ödenen rödovans bedelleri, finansal tablolarda üretim maliyetleri ile ilişkilendirilmeksizin doğrudan çalışmayan kısım gider ve zararları hesabında muhasebeleştirilmelidir. Rödovans payını tahsil eden ruhsat sahibi işletmeler (TKI, TKK ve Yeni Anadolu A.Ş.) tarafından söz konusu rödovans sözleşmelerinde taahhüt edilen üretim miktarı üzerinden kiracı işletmeden madenin tükenme payı karşılığı olarak alınan kira bedelleri kira geliri olarak kaydedilmektedir. Ancak fiili olarak üretim yapılmadan tamamen sözleşme karşılığı olarak alınan paylar ise ruhsat sahibi işletmeler için bir kira geliri değil sözleşmeden doğmuş arızi bir kazanç olarak nitelendirilmelidir.

\section{2. İnceleme Kapsamında Yer Alan İşletmelerin Sahip Oldukları İşletme Hakları Bakımından Değerlendirme}

\subsection{Yeni Anadolu Madencilik ve Teknolojileri San. Tic. A.Ş. (Eski adı Yeni Çeltek A.Ş.)}

Türkiye sınırları içinde yer alan maden yataklarının mülkiyeti devletin tasarrufu altında olup bu madenleri işleten gerçek ve/veya tüzel kişiler sadece işletme hak ve imtiyazlarına sahip bulunmaktadırlar. Bu durum, 3213 Sayılı Maden Kanunu'nun "Devletin hüküm ve tasarrufu" başıklı dördüncü maddesinde "Madenler Devletin hüküm ve tasarrufu altında olup, içinde bulundukları arzın mülkiyetine tabi değildir" şeklinde açıklanmaktadır. Innceleme kapsamında yer alan kömür madeni işletmelerinin maddi olmayan duran varlıkları içerisinde muhasebeleştirilen "Haklar" ve "İmtiyazların" Vergi Usul Kanunu ile Türkiye Muhasebe Standartları bakımından değerlendirilmesi ele alınmaktadır.

Tablo 4. Yeni Anadolu Maden. ve Teknoloji. San. Tic. A.Ş.'ne Ait İşletme Ruhsatlı Kömür Madeni Sahaları

\begin{tabular}{|c|c|c|c|c|c|l|}
\hline \multicolumn{9}{|c|}{ Maden Ruhsatının } \\
\hline Sahibi & Numarası & il/ilçe & $\begin{array}{c}\text { Alan } \\
\text { (ha) }\end{array}$ & Grubu & Durumu & \multicolumn{2}{|c|}{ Açıklama } \\
\hline \hline Yeni Çeltek & 1079 & $\begin{array}{c}\text { Yozgat / } \\
\text { Sorgun }\end{array}$ & 1688,81 & IV & $\begin{array}{c}\text { Iş̧letme } \\
\text { İzinli }\end{array}$ & $\begin{array}{l}\text { Yeni Çeltek Kömür ve Madencilik A.Ş. } \\
\text { tarafından işletilmekte }\end{array}$ \\
\hline Yeni Çeltek & 300 & $\begin{array}{c}\text { Amasya / } \\
\text { Merzifon }\end{array}$ & 1068,75 & IV & $\begin{array}{c}\text { İşletme } \\
\text { İinli }\end{array}$ & $\begin{array}{l}\text { Gürmin A.Ş. tarafından Rödovans karşı̆ığı } \\
\text { işletilmekte }\end{array}$ \\
\hline Yeni Çeltek & 200902340 & $\begin{array}{c}\text { Tekirdağ / } \\
\text { Malkara }\end{array}$ & 1515,04 & IV & $\begin{array}{c}\text { İşletme } \\
\text { İinli }\end{array}$ & $\begin{array}{l}\text { Karma Madencilik A.Ş. tarafından } \\
\text { Rödovans karşılığı işletilmekte }\end{array}$ \\
\hline
\end{tabular}


Yeni Anadolu Madencilik ve Teknolojileri San. Tic. A.Ş. (önceki ismi Yeni Çeltek Kömür ve Madencilik A.Ş.)’ye ait kömür madeni imtiyaz ve işletme hakları (Tablo 4) üzerinden hesaplanacak amortismanlar ile ilgili hususlara değinilmesi yararlı görülmektedir. Özellikle "27. Özel Tükenmeye Tabi Varlıklar" grubu ile ilgili amortisman işlemleri, diğer "25.Maddi Duran Varlıklar" ile "26. Maddi Olmayan Duran Varlıklar" grubunda yer alan iktisadi kıymetlerin amortisman işlemlerine göre bazı farklııklar içermektedir. Uzun süreli işletme hakkı lisanslarının itfası ve işletme hakkının iktisabı için yapılan harcamaların aktifleştirilmesi ile ilgili Balıkesir Vergi Dairesi Başkanlığı'nın 13.05.2011 tarih ve B.07.1.GiB.4.10.15.022010.VUK.127-884- 47 sayılı özelgesinde şu açıklama yapılmıştır: "339, 365, 389 ve 399 Sıra No.lu Vergi Usul Kanunu Genel Tebliğleri ile değişik 333 Sıra No.lu Vergi Usul Kanunu Genel Tebliği eki listenin "Gayrimaddi İktisadi Kıymetler" başlıklı 55'inci bölümünde; işletmenin mevcut değeri, imtiyaz hakları (Franchising), patent, formül, dizayn, örnek kalıp, teknik bilgi (Know-how), format, telif hakkı ve benzeri kalemler, lisans, kullanım hakkı ve izni veya devlet kurum ve kuruluşları tarafından verilen diğer haklar (işletme hakkı gibi) ve bunların benzerleri için faydalı ömür süresi olarak 15 yı $^{*}$, normal amortisman oranı olarak ta \% 6,66* oranı belirlenmiştir." Yeni Anadolu Madencilik ve Teknolojileri San. Tic. A.Ş.'nin Genel Müdürlük hesapları bireysel olarak incelendiğinde; "26. Maddi Olmayan Duran Varlıklar" grubunda yer alan "260. HAKLAR" hesabında toplam 592.169,53 TL bulunduğu, hesabın ayrıntısına bakıldığında ise; 430.799,73 TL'nin tapu kaydı Yeni Çeltek A.Ş.'ye ait olan İR-486 no'lu Bolu ilindeki sahanın itfa bedeli olduğu ve yıllık \%5 oranında amortisman ayrılmak suretiyle itfa edildiği, 164,05 TL'nin teleses bilgisayar programı bedeli olduğu ve yıllık \%25 oranında amortisman ayrılmak suretiyle itfa edildiği, 161.205,75 TL'nin ise patent ve lisanslara (Office programları, muhasebe programları, bordro programı, nes kullanım lisansı, netcad GIS ve netsurf lisans bedeli gibi) ait bedel olduğu ve belirtilen işletme izinli ruhsatlara ilişkin herhangi bir değere rastlanmadığı ifade edilmelidir (Çizelge 2). Bilançoda 26. grupta yer alan maddi olmayan duran varlıkların elde edilme maliyet bedelleri üzerinden hesaplanacak amortisman tutarları, söz konusu iktisadi kıymetlerin ekonomik ömürleri tahmin edilerek işletme bilançolarında aktifleştirilen işletme ve imtiyaz hakları veya maliyet bedellerinin, hangi süre ve oranlar üzerinden giderleştirilerek itfa edileceği, maden sahalarında yer alan toplam ve çıkartılan rezerv miktarları dikkate alınarak belirlenmektedir. Maden kaynaklarının sınırlı olması dolayısıyla maden işletmelerinin ekonomik ömrü de maden yataklarının rezervi ile sınırlı olmaktadır. Ayrıca bu konu ile ilgili husus; 213 Sayılı Kanunun amortisman başlıklı 316. maddesinde "iş̧letme sebebiyle içindeki cevherin azalmasından dolayı maddi değerini kaybeden madenlerin ve taş ocaklarının imtiyaz veya maliyet bedelleri, ilgililerin, müracaatları üzerine bunların büyüklük ve mahiyetleri göz önünde tutulmak ve her maden veya taş ocağı için ayrı ayrı olmak üzere Maliye ve Sanayi Bakanlıklarınca belli edilecek nispetler üzerinden yok edilir" hükmünü amirdir. Buna göre özel tükenmeye tabi varlıkların amortisman tutarları, şu şekilde hesaplanmaktadır:

Madenlerde Amortisman Tutarı = (Imtiyaz veya Maliyet Bedeli / Görünür veya Muhtemel Rezerv) $\times$ Yıllık Üretim

Kanunda değinilen "imtiyaz bedeli" tabiri, imtiyazın alınabilmesi için tanzimi icap eden topografik haritaların yapılması, maden sahasına gönderilen maden mühendisi veya fen memurlarının yol masrafları ve yevmiyeleri gibi masraflarla imtiyaz harcı ve damga resmi gibi harç ve resimleri, "maliyet bedeli" tabiri ise, maden imtiyazının, imtiyaz sahibi tarafından iktisap edilmesi için yapılan bütün giderlerin toplamını ifade etmektedir. Maden istihsali için satın alınan arsa ve arazilerin satın alma bedelinin, maliyet bedeli içinde mütalaa edilmesi zorunlu bulunmaktadır (Akpınar 2012). Gerçek veya tüzel tüzel kişilerin yukarıda belirtilen 3213 sayılı Maden Kanununda yer alan madenleri üretebilmeleri için; (i) işletme ruhsatına sahip olmaları ve (ii) işletme ruhsatına sahip kişi veya kurumlardan ilgili sahanın rödovans karşılığı kiralanmaları gerekmektedir. İşletme ruhsatına sahip olarak madenlerin işletilmesi halinde uygulanacak amortisman yöntemi ile itfa edilecek bedel imtiyaz bedeli olmakta, rödovans karşılığı kiralanmalarda amortisman yoluyla itfa edilecek bedel ise maliyet bedeli olmaktadır. Maden işletmelerinde ortaya çıkan giderlerin, vergi kanunları yönünden doğrudan gider olarak kaydedilmesinde bir sakınca bulunmamaktadır. Ayrıca, VUK'da maden arama ve geliştirme maliyetlerinin giderleştirilmesi/aktifleştirilmesi (maddi olmayan duran varlık olarak) konularında herhangi bir düzenlemeye yer verilmemiş olduğu, sadece harcamaların maliyet bedeli ile kayıtlara alınması öngörülmüş bulunduğu vurgulanmalıdır.

TFRS 6 "Maden Kaynaklarının Araştırılması ve Değerlendirilmesi" standardında sadece arama ve değerlendirme giderlerinin muhasebeleştirilmesine ilişkin açıklamalara yer verilmekte, arama ruhsatının alınmasından önce gerçekleşen giderler ile geliştirme ve üretim giderleri dikkate alınmamaktadır. Söz konusu giderler konusunda TMS 16 Maddi Duran Varlıklar ve TMS 38 Maddi Olmayan Duran Varlıklar standartlarında belirtilen hususların uygulanması işaret edilmektedir. Maden kaynaklarının geliştirilmesine yönelik harcamalar, TMS 38 Maddi Olmayan Duran Varlıklar Standardı hükümlerine göre muhasebeleştirilmelidir. Eğer işletmede maden kaynaklarının restorasyonuna ve kaldııımasına yönelik herhangi bir işlem varsa, TMS 37 Karşılıklar, Koşullu Borçlar ve Koşullu Varlıklar standardı esaslarına göre temel mali tablolara yansıtılması gerekmektedir. Kaynaklar, ilk muhasebeleştirme işlemi sonrasında maliyet veya yeniden değerleme modeline göre değerlenmelidir. Muhasebeleştirme işlemi sonrasında maden kaynakları mutlaka değer düşüklüğü 
testine tabi tutulmalı, herhangi bir değer düşüklüğünün tespit edilmesi halinde ise zarar olarak mutlaka kayıtlara alınması gerekmektedir.

Maddi olmayan duran varlıkların VUK ve TMS açısından değerlendirmesi yapıldığında; vergi mevzuatı, daha çok objektif, saptanması kolay, işletme sahip ve yöneticilerine, belirleme hakkı bırakmayan tartışmasız somut ölçüleri kabul etmiş olup, genelde varlığın, işletmeye maliyeti üzerinde yoğunlaşmaktadır. Muhasebe standartları ise, daha subjektif, işletme sahip ve yetkililerince piyasa koşullarına göre belirlenip değiştirilebilecek, varlığın geçmiş maliyetinden çok, gelecekte elde edilebilecek tutarını içeren ve özellikle de "makul değer - gerçeğe uygun değer" ölçüsünde içerik bulan değerleme ölçülerini kabul etmektedir (Başağaç 2006). İşletmeler tarafından, TMS 36 Varlıklarda Değer Düşüklüğü Standardı'na göre maddi olmayan duran varlıklar gibi iktisadi kıymetlere ilişkin değer düşüklüğü testi yapılarak (varlığın defter değerinin, geri kazanılabilir tutarından yüksek çıkması hali) her bilanço döneminde varlığın değerinin düşmüş olabileceğine ilişkin göstergeler kontrol edilmeli ve temel amaç olarak finansal tablo kullanıcılarına güvenilir bilgi sunmak olduğu düşünülen TMS'lere (özellikle TMS 36) göre oluşan değer düşüklüğü zararı, (TMS 36, Mad. 61'e göre) mutlaka muhasebeleştirilmelidir.

\section{Genel Değerlendirme ve Sonuç}

Bugün itibariyle gerçeğe uygun muhasebe anlayışı çerçevesinde Türkiye'de yürürlükte bulunan üç ayrı düzenleme vardır. Bunlar sırasıyla; TC Hazine ve Maliye Bakanlığı tarafından yayımlanan kural temelli Muhasebe Sistemi Uygulama Genel Tebliği (MSUGT), Kamu Gözetimi, Muhasebe ve Denetim Standartları Kurumu (KGK) tarafından yayımlanan ilke temelli Türkiye Muhasebe ve Finansal Raporlama Standartları (TMS/TFRS) ve Yerel Finansal Raporlama Çerçevesi (YFRÇ)'dir. 2011 yılında yayımlanan Yeni Türk Ticaret Kanunu, sermaye şirketlerinde muhasebe sistemlerinin ve finansal raporlamaların 01 Ocak 2013 tarihi itibariyle Türkiye Muhasebe Standartlarına (TMS) göre uyumlu olmasını zorunlu hale getirmiştir (TTK madde 64 ve 88). Ancak bugün geldiğimiz noktadaki muhasebe uygulamalarına bakıldığında başlangıçta gerçeğe uygun olarak benimsenen muhasebe anlayışının halen ağırlıklı olarak vergi mevzuatının etkisi altında kaldığı ifade edilmelidir (Anonim 2021c). KGK tarafından TMS ve TFRS uygulamalarına yönelik hükümlerin revize edilerek, bağımsız denetime tabi işletmelerin kapsamının sınırlandırılması ve gerçeğe uygun muhasebe uygulamalarının sadece bağımsız denetime tabi işletmeler için zorunlu tutuluyor olması buna en güzel örnek olarak verilebilir. Bu itibarla; özellikle çalışmamızın da konusunu oluşturan kamu kurum ve kuruluşları ile müessese, iştirak ve bağlı ortaklıklarında arzu edilen muhasebe kültürü bir türlü oluşmamakta ve dolayısıyla düzenlenen temel ve ek mali tablolara da gereken önem verilmemektedir.

Bu çerçevede incelemeye esas işletmelerde tespit edilen hususlar şu şekilde belirtilebilir;

- MSUGT ve tek düzen hesap planının ruhuna uygun olarak maddi olmayan duran varlık alımlarının (bilgisayar ve makine yazılımları, fikri hak alımları ve bunların güncelleştirme bedelleri vb.) muhasebe kayıtlarında doğrudan giderleştirilmesi yerine 260. Haklar hesabına kayıt edilmesi,

- 260. Haklar hesabında izlenmesi gereken iş makineleri ve bilgisayar yazılım programlarının 267. Diğer Maddi Olmayan Duran Varlıklar hesabında takip edilmesi,

- Kiralık olarak tutulan lojman, bina, depo vb. yapılar için yapılan değer artırıcı işlemlerin 264. Özel Maliyetler hesabında takip edilmesi,

- Lojman, depo, idari bina, su deposu, kantar binası, silo, vinç vb. zemin etüdü ve statik proje çizimi masraflarının 260. Haklar hesabı yerine doğrudan giderleştirilmesi,

- Gelecek yıllarda doğması muhtemel “Hak ve Yükümlülüklerin” takibinde “Nazım Hesapların” kullanılması,

- Araştırma ve geliştirme (Ar-Ge) giderleri birbirlerinden ayırt edilmeli ve araştırma giderlerinin aktifleştirilmemesine özen gösterilmesi,

- Işletme aktiflerinde kayıtlı maddi duran varlık (MDV), maddi olmayan duran varlık (MODV) ve özel maliyetler (ÖM)'ler için amortisman ve tükenme paylarının doğru bir şekilde hesaplanıp hesaplanmadığının takip edilmesi,

- Bilanço dönemi içerisinde satılan MDV ve MODV kalemlerinden elde edilen kar/zararın doğru bir şekilde hesaplanıp hesaplanmadığının kontrol edilmesi gerekmektedir. 
Gerek inceleme kapsamında yer alan iktisadi devlet teşekkülleri gerekse diğer kamu iktisadi teşebbüsleri ile müessese, iştirak ve bağlı ortaklıklarına ait varlıkların uluslararası değerleme ve muhasebe standartlarına, tekdüzen hesap planına uygun olarak raporlama işlemlerinin finansal tablo kullanıılarının, potansiyel yatırımcıların, karar alma noktasında bulunan üst düzey yöneticilerin intiyaçlarını karşılayacak nitelikte yürütülmesi ve kaynak israfından vazgeçilmesinde kamu menfaati bulunmaktadır. Bu çerçevede kamuya ait kıt kaynakların ihtiyaca uygun, etkin ve verimli bir şekilde kullanılması, özellikle söz konusu kurumlarca yabancı kaynak kullanımında banka ve finans kurumları tarafından yersiz hesaplanacak risk puanlarına maruz kalınmaması amacıyla finansal tablolarda yer alan iktisadi kıymetlerin gerçeğe uygun güncel değerlerinin belirlenmesi ve muhasebe kayıt nizamının buna göre oluşturulması gerekmektedir. Zira gelişen dünya ekonomisi içerisinde finansal anlamda en güçlü işletmeler, artık en yüksek derecede maddi duran varlıklara sahip olan işletmeler yerine mevcut entelektüel sermayelerini güçlendiren ve bunu da en etkili ve verimli bir şekilde yönetip kullanan işletmeler olacaktır.

\section{KAYNAKÇA}

Akpınar, A. (2012). "Uluslararası Finansal Raporlama Standartlarına Göre Amortismana Tabi Duran Varlıklar ve Türkiye Uygulaması". Gazi Üniversitesi Sosyal Bilimler Enstitüsü, Doktora Tezi, Ankara.

Aliefendioğlu, Y., Demir, E., \& Tanrıvermiş, H., 2016. Kamu Iktisadi Teşebbüslerinin Aktiflerinde Yer Alan Maddi Duran Varlıkların Envanter ve Değerleme Araştırması: Elektrik Üretim Anonim Şirketi Genel Müdürlüğü Hirfanlı Hidroelektrik Santrali İşletmesi Örneği, s. 47, Finans ve Bankacılık Çalışmaları Dergisi IJFBS, Cilt 5 Sayı 5, Özel Sayı ISSN: 2147-4486.

Anonim, (1992). "1 Sayılı Muhasebe Sistemi Uygulama Genel Tebliği". 26.12.1992 Tarih ve 21447 Sayılı Resmi Gazete Mükerrer Sayısı

Anonim, (2015). "Beyanname Düzenleme Kılavuzu 3. Cilt Vergi Usul Kanunu”, Maliye Hesap Uzmanları Derneği Yayınları, s. 167, İstanbul, 2015.

Anonim, (2021a). "TMS 38 Maddi Olmayan Duran Varlıklar Standardı". 8. paragraf,

Anonim, (2021b). "TMS 38 Maddi Olmayan Duran Varlıklar Standardı" 21. paragraf,

Anonim (2021c). TMS 38 Maddi Olmayan Duran Varlıklar Standardı, Kamu Gözetimi Kurumu.

Başağaç, H. (2006). "Maddi Duran Varlıkların Değerlemesinde Türk Vergi Mevzuatı ve TMS 16: Maddi Duran Varlıklar Standardı Hükümlerinin Karşılaştırılması”, Gazi Üniversitesi Sosyal Bilimler Enstitüsü, Yüksek Lisans Tezi, Ankara. 